\title{
RE-THEORIZING SILENCE(S)
}

\section{RE-TEORIZANDO O(S) SILÊNCIO(S)}

\section{Stephanie Power-Carter}

\begin{abstract}
This paper describes a telling case account that occurred during an ethnographic study in the United States in a secondary school senior British Literature class with only two African American young women, Pam and Natonya. The telling case complicated silence and also made visible other reflexive processes that provided opportunities to unpack and theorize silence, which led to the articulation of the silence trilogy. Further, it also made visible how the African American woman scholar's own lived experiences informed her attempt to make sense of how Pam and Natonya navigated the silence(s). This paper will primarily foreground the works of Scholars of Color and use Black feminist and sociolinguistic theory to explore the following question: How did two African-American females in a predominately white educational space negotiate the silence(s) (e.g., silence, silencing, and silenced)? How did the African American woman researchers of color make sense of their negotiation?
\end{abstract}

Keywords: re-theorizing silence, literacy, and african american young women.

\section{RESUMO}

O presente artigo descreve um estudo de caso que ocorreu durante um estudo etnográfico nos Estados Unidos em uma aula de Literatura Inglesa do Ensino Médio com duas jovens afroamericanas, Pan e Natonya. O estudo de caso revelou o silêncio e outros processos reflexivos que criaram oportunidades para desvendar e teorizar o silêncio, o que levou à articulação de uma trilogia do silêncio. Além disso, também tornou-se visível como as experiências de vida da pesquisadora afro-americana informou suas tentativas de compreender como Pam e Natonya navegaram no(s) silêncio(s). O artigo ancora-se nos trabalhos de pesquisadoras/es negras/os, no Feminismo Negro e em teorias da sociolinguística para explorar as seguintes questões: Como duas mulheres afro-americanas em um espaço predominantemente branco negociam o(s) silêncio(s) (por exemplo, silêncio, silenciamento, silenciada)? Como pesquisadoras afro-americanas negras constroem sentidos sobre essa negociação?

Palavras-chave: re-teorizando o silêncio, letramento, jovens mulheres afro-americanas.

\section{INTRODUCTION}

This paper describes a telling case that emerged from an ethnographic study that took place in the United States in a predominately white senior British literature classroom with only two African American young women, Pam and Natonya. Data were generated through participant observations, fieldnotes, audio

\footnotetext{
* Indiana University, the United States. powercarter2000@gmail.com.

Orcid: https://orcid.org/0000-0002-4643-853X
} 
and videotaped ethnographic interviews, and artifacts. As I observed how Pam and Natonya negotiated their racial and gendered identities in a British literature class, dominated by literature written from a Eurocentric perspective, primarily by White males, a telling case began to emerge. According to Mitchell (1984), a telling case is a particular circumstance that serves to make "previously obscure theoretical relationships suddenly apparent" (p. 239). Specifically, the telling case that emerged began to demonstrate the dynamic nature of silence, particularly that silence is not always a void space, but it can also be a space of rich conversation and agency.

In complicating silence, the telling case additionally began to illustrate how Pam and Natonya also negotiated silencing and being silenced. What is unique about this particular telling case is that the case itself begins to make visible other processes and provide opportunities to both theorize silence, and unpack what I call the silence trilogy; it also begins to articulate and make visible how I, a woman of color scholar, moved reflexively between, across, through, and within the professional context to the personal context to make sense of how Pam and Natonya were negotiating silence. Specifically, this paper will explore the following questions:

- How did two African-American females in a predominately white educational space negotiate the silence(s) (e.g., silence, silencing, and silenced)?

- How did the African American woman researchers of color make sense of their negotiation?

Building on the work of Mitchell, 1984; Sheridan, Street \& Bloome, 2000, I present a telling case using an analytic approach that engages a reflexive turn, I acknowledge that as an African American woman researcher, I was not abstractly engaged in this research with Pam and Natonya. Collins (1991), a Black feminist theorist writes, "Black women scholars are often called on "to produce facts that will clarify a Black woman's standpoint ... (p. 37). Thus, I also drew on my own memory and history for this study and paper.

It is equally important to note that while this paper includes scholars in the field of language and literacy broadly to unpack silence more deeply and capture the processes that emerged, as I engaged in a process of exploring the experiences of two African American young women, I constructed an analytic approach that is interdisciplinary in nature and grounded in the wisdom and knowledge of Black people. Particularly, I draw extensively on the works of scholars of color that may not be widely known in the field of language and literacy studies. I do so because it was not only necessary in order to fully understand these two African American 
young women's experiences, this process was also necessary to provide a model for how the field might acknowledge the unique experiences of scholars of color and those from historically underrepresented backgrounds.

Thus, all too often, scholars of color are marginalized and left with little options or academic spaces to fully unpack and capture the reflexive, recursive and iterative process that they engage as insiders within the communities of color that they study (e.g., WILLIS, 2008). Particularly, few opportunities exit that support ways in which their own linguistic and cultural resources inform how they see and understand the nuanced and strategic ways that people and communities of color make meaning and sense of their social worlds in and through language and literacy. Akbar (1985), situates the unique experiences and goals of Black scholars in the following: "the general role of the Black social scientist is to alter the framework of dominant culture reality, so they might accommodate new frames of reality, marginalized viewpoints, and expand paradigms (as cited in PAUL, 2003, p. 2).

Foregrounding scholars of color in my approach to writing this paper reflects Akbar's argument, given that it was critical in providing a lens to better understand and articulate how Pam and Natonya's navigated silence(s) and also the processes that begin to emerge while making sense of their navigation. In this review, therefore, I presented a conceptual review of literature, primarily by U.S. scholars of color, who have focused on theorizing the Black experience. In doing so, I brought to the forefront conceptual and empirical research that has laid a foundation for (re)theorizing silence as a space for productive resistance and work, as well as for developing deeper understandings of Black young women in the context of US schooling and social life.

My goal in foregrounding this group's experiences was to do the following: (1) to raise issues for international scholars to consider how silence(s) might be functioning for historically marginalized communities; (2) to consider what literature one might need to draw from in an effort to see more fully how those from historically marginalized groups engage in language and literacy; and (3) to call for the scholarly community to understand more fully "what those who have it can do with it; what they have made of it, and do make of it... (HYMES, 1974, p.72). Moreover, I framed issues that begin to provide opportunities for scholars to see differently and to make visible blind spots and complexities that researchers studying historically marginalized groups in other national contexts might not otherwise see. Specifically, the arguments presented through the literature review to this point also makes visible how our own histories and experiences as researchers can, and often do, inform how we see whom (persons being studied), and what we 
see the person(s) doing. In the next section, I present a review of literature that frames, complicates, and reframes silence. Following this literature review, I will present evidence of how Silence, Silencing, and Silenced were experienced by Pam and Natonya.

\section{FRAMING SILENCE: A CONCEPTUAL REVIEW OF LITERATURE IN US}

Today in the US, there is a rich body of scholarship from scholars of color that has led to deeper understandings of the linguistic turn (e.g., BAUGH, 2010; HALL, 1990; MORGAN, 1997; RICKFORD, 1999; SMITHERMAN, 1986). Given that deficit models are still prevalent in today's discourse not only does more work need to be done, but also more space needs to be created to learn from this body of work and to theorize. Thus, it is crucial to continue to provide opportunities for such scholars to theorize these language and literacy interaction as their unique positions and cultural resources often afford them to see differently.

However, one blind spot in studies of language in use is that the work of scholars of color is often not included in major literature reviews. Therefore, if we fail to be more inclusive in such reviews, we run the risk of facilitating intellectual and theoretical blind spots that under-complicate how communities of color engage language and literacy. As the review of literature on silence undertaken by scholars of color that follows will show, we also overlook the rich and important work that scholars of color have undertaken to frame issues of language and silence; we limit what can be learned about language in educational spaces and how interpretations of such language of Black young women can lead to deficit assessments of the young learners.

Further, through the review of literature, I will show that such a view is at best limited and is unable to fully take into account power differentials or the relationship of people in contexts where language and literacy are the focus of educational events. Additionally, it is important to note that while we have a number of theories about how language is developed in different communities around the world; however, to date there are still blind spots that can have implications for communities of color, those from historically marginalized groups as well as scholars of color and those from historically marginalized groups engaged in scholarship with them (TUCK, 2009). In acknowledging the complexities of these relationship between language and people, researchers and communities, we must also acknowledge that these relationships are imbued by histories and social worlds that can have consequences for peoples everyday lives. Hymes (1974) notes: 
If linguistic research is to help as it could in transcending the many inequalities in language and competence in the world today, it must be able to analyze these inequalities. In particular a practical linguistics so motivated would have to go beyond means of speech and type of speech community to a concern with persons, social structures [and local literacies] (204-05).

While some in the field of linguistics have acknowledged the multiplicity of perspectives, experiences, and areas that have informed literacy studies (e.g., BLOOME et al. 2005; HYMES, 1974; STREET, 1995), little has been done to expand how the field makes room for, and provides opportunities for scholars of color, or those from historically marginalized groups in the communities of color that they study, to theorize and make sense of the literacy processes and practices being studied. This work attempts to demonstrates that it is important to not only capture how particular participants use language to navigate and make sense of their social worlds, but to also make visible the processes and cultural resources that inform researchers of color's own understandings of how their participants move in and through doing language and literacy (PAUL, 2003).

Thus, the challenge for the field is not just how do we make space for particular groups of scholars, who might be uniquely positioned to capture that which is invisible to others. Bloome et al (2019) argue that Street might frame the following argument: how do we begin to grapple with examine, re-examine, extend, retbink, and correct, ideas and theories that bave traditionally informed and framed bow we engage literacy research. In this spirit of grappling, I present ways of theorizing and studying silence as a blind spot in studies of the education of Black Young women in and out of schooling contexts.

\section{PERSONAL ROOTS: BLACK FEMINIST PERSPECTIVES}

Similar to Gumperz and Hymes (1972), I argue that cultural worlds are very present in our research. Thus, while theorizing silence has been a 20 plus year journey that represents my life's work, this personal process has been complicated given that there have been few spaces to publish work that theorizes silence as a cultural process and lived experience in social spaces. This limitation has meant that until this call for studies for the explicating research approaches framed by the Research Network on Literacies in Social Spaces of AILA, I have been unable to find a place to publish and share my research process and work on silence(s). Unfortunately, there are few theoretical frames that are acknowledged within the field that build on and extend this state of affairs that persists still today, particularly in the US context. Whether and how this relates to directions in research and theory in other 
countries is still to be explored. Thus, my exploration of silence(s) that I present in this paper may appear to some who are unfamiliar with the experiences of Black Young women, particularly those in the U.S. as personal, when in actuality it has been nurtured and informed by multiple tributaries of knowledge and experiences, both personal and professional.

One critical source of influence that frames this process is the following argument by bell hooks (1991), a prominent Black feminist scholar who writes about her personal journey to becoming a scholar in the field of Black feminist studies as follows: "I came to theory desperate, wanting to comprehend to grasp what was happening around and within me." (p.1). In this statement, she makes visible the complex challenges of her journey as well as what her work sought to understand as part of her journey in becoming a theorist.

Similar to bellhooks' journey, I came to theory about silence as a Black woman scholar, daugbter, sister, cousin, friend, community member, and former teacher trying to make sense of, and better understand silence. The following section represents a vivid memory between my mother and me during my research and interactions with Pam and Natonya. While I am unsure of the timing of this interaction with my mother, this memory along with my interactions with Pam and Natonya helped me see silence differently.

\section{EXPLORING SILENCE(S) THROUGH LIVED EXPERIENCES: ME, MOM AND SILENCE(S)}

I often find myself concerned with peeling away layers, margins, blind spots, and thinking about ways of seeing. It is through this process that I began to, and continue to explore invisibility, inequity, the who, the bow, the what of silence. However, I have come to realize that while my conscious journey with silence(s) began in the early 90s as I was immersed in graduate school studying Black feminist theory and engaging in a study on Black young women in public schools. For me, theorizing silence has been a dynamic reflexive exploration greatly informed by the memory of an experience with my mother. It was this experience that forced me to see and think about silence differently. In fact, this experience with my mother has been crucial and integral to my understandings of nuance and complexity of the experiences of Black young women and silence(s).

While other scholars might frame this reflective memory with my mother as a moment of wondering and a rich point where culture happens (Agar, 1994; 2006), in the spirit of this paper, I use Dillard's (2012) theorizing of cultural memory, who 
herself is a woman of color, because it better situates my experiences as a woman of color in community with her mother while researching young women of color. She argues that:

Our collective memories are less about an intellectual "truth" than they are about what we are referencing, what we are working to construct, what we desire to put back together again...I am arguing here that such memory work is critical for marginalized peoples, in order to see ourselves more clearly, in order to see how we are mutually recognized, mutually (re) membered, mutually mediated (ANZALDUA, 1999; MORGA \& ANZALDUA, 1981; FERNANDES, 2003). They are the memories that reference the place that holds us to the earth, the ways we are because we have been (12).

While Dillard cautions that memories must move through and beyond dualities, her notion of memory is helpful in understanding how the following experience with my mother was about seeing and realizing the mutuality and connectedness of our experiences as women of color as we navigated silence. It made visible a nuanced dialogic consciousness, imagination of sight captured in the African philosophy of Ubuntu--I am because you are, and I see you. I see me in you (e.g., DILLARD, 2019; POWER-CARTER, 2019). Moreover, as Dillard (2012) captured the connectedness and resilience, she also made visible contexts and tensions embedded within that consciousness. Du Bois (1903) refers to this consciousness as an internal cultural tension, one he frames as double consciousness.

To contextualize the aforementioned memory of an interaction that I had with my mother, I began by recalling that I had driven home for a break to spend some time with my mom. My mother is the second oldest of ten brothers and sisters. She had dropped out of school to help her mother around the house, but she later went back to school, attained a G.E.D (General Education Diploma or High School Equivalency Certificate) and took classes at local technical college. Prior to my epiphany on silence, I always thought of my mother as the epitome of a "stereotypical," Southern Christian woman. She married young and gave up her life-long dream of becoming a nurse because she didn't have the support system needed for the hour commute and classes. A little over a year after my mom and dad married, my sister, and then me, entered the scene. In fact, there was only one thing my mom did that was pretty unique and unlike some of the local married woman; she worked outside of the home.

For most of her life and my formative years, she worked as a pre-school assistant director and later as a nurse's assistant, hoping that perhaps it would ignite her desire to go back and finish nursing school, but she never went back. Every day, Mom cooked a full meal, and I distinctly remember her making my Dad his favorite homemade butter biscuits from scratch. We always had Sunday breakfast and dinner 
together as a family. In fact, mom still makes homemade biscuits, preserves, and jams. While my mother is quick witted and will definitely not hesitate to speak truth in a situation, I don't think I have ever heard her curse. Her presence has always been gentle, nurturing, caring, and kind.

As a child, I had no memories of her raising her voice at me in anger. While I absolutely unequivocally love my mother, as an educated Black young woman, at that stage in my life, I saw her as passive, and as much as it pains me to write this, in my ignorance, I saw her as weak at that time. With age and wisdom, I have come to understand my mother and appreciate the sacrifices that she made. However, it was not until a conversation and observation of my mother in her day-to-day context as I was simultaneously in the midst of my study with two young Black women that I began to complicate silence. Perhaps equally importantly, as a scholar, I began to see differently. The excerpt in Table 1 below is a reflection that captures when I realized that I should think of silence in more expansive, complicated and transformative ways.

\section{Table 1. Remembering Silences}

It was as if for that moment, I stood in the field of her memories, her bopes, ber dreams, and her despair. The remnants of her past were visible today, and her joints reeked of the damage done by fluffy White patches of cotton from ber youth. She moved slowly as if the weight of years were on her shoulder. "Mama why do you let those people treat you that way on your job? Why don't you say something?" Deep inside I wanted to cleanse myself from the stench and memory of her past. I wanted to cleanse ber too. If I could only erase those famous words that always trickled off ber tongue when things seemed unfair. "It won't be like this always." I hated those words. Did she know something that I didn't know? Those words seemed to suggest that my mother was not strong, that all ber words bad been suffocated out. Where was ber fight? I stared at ber across the kitchen thinking bow different our lives were.

She must bave read my mind because she said, "I am okay." Then, she reached over and touched my shoulder. "Sit down for a while. I know it might not look like it, but I am bappy." But mama -wby don't you speak why don't you say sometbing?" My mother looked at me surprised. "I do speak up for myself. I might not speak the way you think I should, but I speak!"

I was surprised at her tone. For once, my mother seemed a little aggressive. Then the phone rang. It was one of my mother's friends; I sat at the kitchen table as she sat across from me discussing ber work experiences with this woman-this other African American woman. My mother's words seem to spill out so naturally, ber body accentuating every syllable, giving advice -joking-something seemed to pull words out of her. It was almost like bearing ber for the first time. She wasn't weak or passive. I discovered that I could bear my mother's voice. I realized that I, just like much of society bad labeled my mother by trying to describe and define her experiences through a lens that could not begin to capture the complexities and intricacies of ber life as an African American woman in America.

After the above exchange, I began to realize that over the years my mother and other women in my family had not only taught me how to speak, but most of all how to listen to silences in between the words through the little kitchen conversations, the gestures, phone conversations, and the sofa chats. I learned that the silences in between the spoken words were full of rich non-verbal communication and loaded 
with meaning. Throughout the years, my mother had been cultivating my ability to listen and navigate silence(s). When I was a child, she always surrounded my sister and me with strong women-our aunts, great aunts, grandmothers, and great grandmothers. Although often there were no words to express their experiences or feelings, I heard their struggles; their "silence" was deafening.

In the sections that follow, I will make visible how I engaged in a process to "complicate silence(s)", by presenting the reflexive, dynamic and iterative process that I utilized to make visible blind spots, in which silence, as a cultural process, is embedded in the lives of African American students and others in the US context. Specifically, through this process, I make transparent how I examined and reexamined how silence functions in the social worlds of these two Black young women in a British literature classroom in the US.

\section{COMPLICATING SILENCE(S): AN OVERVIEW OF PERSPECTIVES}

Often scholars across disciplines have primarily thought of silence as the absence of presence, or voice (e.g., FORDHAM, 1993; LADSON-BILLINGS, 1996; MARRIOTT, 2003). Tannen \& Saville-Troike (1985) writes, "Within linguistics, silence has been traditionally ignored except for its boundary-marking function. The tradition has mostly been to define silence negatively-as merely the absence of speech" (p.4). Although this is one way of defining silence that has been used to understand the plight of some people of color, particularly African American women, it can become problematic. Such a perspective can simplify silence(s) and also capture it using white male paradigms to explain African American female experiences. While thinking of silence as lack or deficiency might be helpful in some circumstances or in relation to particular contexts and participants, it does not fully capture the complexities of silence(s) and/or how silence(s) can be thought of as a transformative and powerful space, that is purposefully used by particular participants for particular purposes.

The field of education is beginning to understand that traditional and dominant definitions of silence(s) as non-participatory can be problematic for women of color. Although this view of silence acknowledges some of the challenges that Black women face, as I will demonstrate in this paper, it fails to fully capture the nuanced ways that women of color use their bodies to strategically navigate and respond to Whiteness in particular contexts (e.g., classrooms and/ or educational settings). Maher \& Tetreault, (1997) notes that "Whiteness is an invisible basis against which other racial and cultural identities are named as 'other' 
and are measured and marginalized" (p. 324). The construction, reproduction, and interpretation of Whiteness is informed by "historical moments," "region," "political climate," and "racial identity" (BABB, 1998; DYER, 1997; FRANKENBERG, 1998; ROEDIGER, 1994).

While the roots of studies of silence can be traced to studies by linguist and feminist scholars, who have explored silence(s) for some time (e.g., CHEUNG, 1993; HUEY-LI; 2001; CARANFA, 2004; HIGGINBOTHAM, 1992; RICKFORD, 1999; TANNEN \& SAVILLE-TROIKE, 1985), recently scholars in the field of education (e.g., POWER-CARTER, 2001; SAN PEDRO, 2015; 1996; ZEMBYLAS \& MICHAELIDES, 2004) have begun to explore and view silence as more than a monolithic space without speech. This developing perspective views silence as complex phenomena that can provide insights and understandings on how students of color negotiate and navigate whiteness within schools and our curriculum.

\section{RE-FRAMING SILENCE(S)}

Because there have been few theoretical frames to build upon in the field to reframe silence as it relates to Black young women, this article draws on the work of Black Scholars (e.g., BETHUNE, 1938; COOPER, 1988; Du BOIS, 1903; HURSTON, 1928; WOODSON, 1933), as well as Black feminist theory and Sociolinguistic theory as theoretical lenses to explicate and complicate silence. From a Black studies and Black literary perspective, Nobel Prize author, Tony Morrison (1993) in her Nobel Prize Speech notes,

The systematic looting of language can be recognized by the tendency of its users to forgo its nuanced, complex, mid-wifery properties for menace and subjugation. Oppressive language does more than represent violence; it is violence; does more than represent the limits of knowledge; it limits knowledge.

In this statement, Morrison (1993), a well-known African-American author, challenges us to ponder not only how language informs how we think, but also how we think about others and ourselves. This is particularly important for scholars from white male European backgrounds. She also calls us to think about how our thoughts can materialize into actions that can ultimately have positive and/or negative consequences for people, particularly those from historically marginalized groups.

Black feminists provided another body of literature and was selected given its focus on foregrounding Black women's experiences and its examination of the interrelationship of whiteness and male superiority (COLLINS, 1990; 
GIDDINGS, 1984; LORDE, 1982; SMITH, 1985). Black feminist theorists argue that notions of whiteness and male superiority have historically "silenced" Black women (COLLINS, 1990). However, Black feminist theory not only provides ways of framing how whiteness and ideological stances negatively position black women, it also provides a lens to capture their resilience, creativity, and alternative interpretations of how they navigate and negotiate their identities in the midst of whiteness. This latter relationship is critical, as I will show, to the iterative and reflexive analysis that I present in later sections of this paper, in which I present analyses of Pam and Natonya's experiences in their British Literature class.

Moreover, as I will further demonstrate, sociolinguistics theory supports the analysis I undertook, given that it foregrounds language, particularly how people act, interact, as they engage in doing language and literacy (BEACH \& BLOOME, 2019; ZAHRLICK and GREEN, 1991). Foregrounding language and literacy and how people use language is important because inequity is often concretized through language and blind spots are made visible to those who perpetrate and navigate them (POWER-CARTER \& ZAKERI, 2019).

Using Black feminist theory and sociolinguistics theory as theoretical lenses affords an opportunity to center the lived experiences of Black woman, and to complicate silence(s) as they engage in language and literacy learning in educational contexts. For example, a Black young woman moving her neck too much or rolling her eyes are often perceived as disrespectful. All of these gestures ultimately become generalizations and representation of the "angry Black woman;" rather than understood as sophisticated strategies that Black women utilize to communicate, affirm each other in oppressive situations, or as forms of survival and opposition. If researchers are not careful, it is easy to simplify the actions of particular participants in these powerful spaces of non-verbal communication. This caution was framed by Adichie (2009), an African scholar and writer who warns of "the danger of a single story," as she recounts an experience with her American college roommate. She states:

She had felt sorry for me even before she saw me. Her default position towards me, as an African, was a kind of patronizing well-meaning pity. My roommate had a single story of Africa, a single meaning of catastrophe. In this single story, there was no possibility of African being similar to her in any way. No possibility of feelings more complex than pity.

Adichie's (2009) caution frames the need to consider and examine the presuppositions that participants bring to particular contexts (GUMPERZ, 1984). 
Unfortunately, research on how Black young women are positioned in classrooms, has shown that some Black young women are negatively positioned in school contexts as a result of their non-verbal communication (POWERCARTER 2001). Often times, these characterizations are misguided and depict Black young women in "single" and simplistic ways. Further, it is usually the case that school personnel seldom focus on the various ways that schools and schooling perpetuate an oppressive context for Black young women (e.g., FINE, 1987/1991; FORDHAM, 1993; HARRISON, 1997; MADDUX, 1997; MORRIS, 2016; MUHAMMAD \& HADDIX, 2016). Such studies provide simplistic interpretations of Black young women that become consciously and unconsciously inscribed in policies and behaviors that further marginalize Black young women in the school context (BLAKE et al, 2011; CAMERA, 2017; MORRIS, 2016; WUN, 2016). Unfortunately, a review of literature on this issue shows that school is a context that is seldom critiqued or analyzed for how whiteness perpetuates a "single story" of Black femaleness. Scholars (FORDHAM, 1993; HARRISON, 1997; HENRY, 1994; LEE, 2001; LEWIS, 2003: MUHAMMAD \& MCARTHUR, 2015) have found that schools are often problematic because they privilege Eurocentric ways of knowing and engaging that are culturally problematic for African American students by reinforcing a system that views them as inferior and failing (BROWN et al. 2017; FULLER, 1980)

Rather than viewing Black young women's use of non-verbal communication negatively, simplistically, or in a traditional view of silence(s), I argue that we consider these spaces as rich spaces of community and agency, i.e., spaces where Black women use non-verbal communication as strategies of engagement (e.g., choosing not to speak, how to speak, and with whom to speak). By acknowledging the silence(s), I begin to complicate a "single" view of silence and Black femaleness. In doing so, I also begin to positively reposition young Black women's ways of knowing and engaging. An examination of silence(s) from the perspective of Black women is critical in order to fully understand how Black young women in schools navigate silence(s) and whiteness.

\section{COMPLICATING SILENCE AS THE "INSIDE THING": AN ETHNOGRAPHIC STUDY OF SILENCE(S) THROUGH SCHOOL}

Recently there has been an increase of studies on Black young women in educational context (e.g., ANYON, 2014; CARTER, 2001, GILLAM, 2017; JONES 2009; MORRIS, 2007; MUHAMMAD, 2012; MORRIS, 2016; ROLLOCK, 2007; 
SEALEY-RUIZ, 2016; WINN, 2019; WUN, 2016). These scholars address the unique challenges that young women of color navigate in schools. This section will utilize the voices of Pam and Natonya, the only two African American young women, in an ethnographic study that I conducted in a public high school British Literature class (e.g., POWER-CARTER, 2001). Examining video data, field notes, and interview conversations with Pam and Natonya, I attempt to complicate silence(s).

The interview transcript excerpts below form an anchor, a rich point to this transcript (AGAR, 1994/2006). It begins to make visible how these young black women both began referencing spaces that initially looked like silence but were actually full of non-verbal communication that Natonya labeled as the "inside thing." During an interview conversation that I had during my ethnographic research, Natonya states:

Table 2. Natonya's inscriptions of Spaces and Perspectives on Perceptions of Black African American Females

Natonya: it's like when, every time we [Black females] like see something we don't like, or somebody say something to us, we roll our eyes or, twitch our lip or something like that, you know? And it's like, we have this so-called attitude, that we get and everything, which, some people say we sensational. You know? And so, it's like uh. And, and it's like many, many Black African American females have they own, face expression, either when they mad, when they don't like something, when somebody say something to them and they don't like it, you know what I'm saying

In the above interview conversation segment, Natonya began to share how she believes that Black women use non-verbal communication to navigate whiteness. When I followed up with both of the young women during another interview conversation, what became clearer was that they were using nonverbal communication as strategy, particularly when they felt negatively positioned in the classroom.

\section{CONTEXTUALIZING THE "INSIDE THING"}

In this section, I frame the context that was crucial in capturing the "inside thing" and complicating silence. Natonya and Pam had been given a Director's notebook assignment. The Director's notebook consisted of a chart that students had to complete that addressed the following aspects of a scene from literature: text, meaning/interpretation, actions/movements, facial expressions, music, sounds, costumes, sounds, and stage set. The teacher also shared scenes from previous years 
from an American history course. The transcript below focuses on an excerpt from this assignment-- a particular student director's notebook from Mark Twain's book, Huck Finn. In this transcript, the student acts out Tom and Huck's part. At the end when the student is explaining the scene he chose to act out from his notebook, he is sitting in his bedroom and above his bed a confederate flag is draped on the wall. The confederate flag in the US is a highly controversial symbol that is often associated with slavery, racism and hate groups (e.g., Nazis, Klu Klux Klan)

The teacher felt that this particular assignment was a "good example" of a director's notebook. The classroom transcript and non-verbal transcript of the Natonya and Pam is presented below.

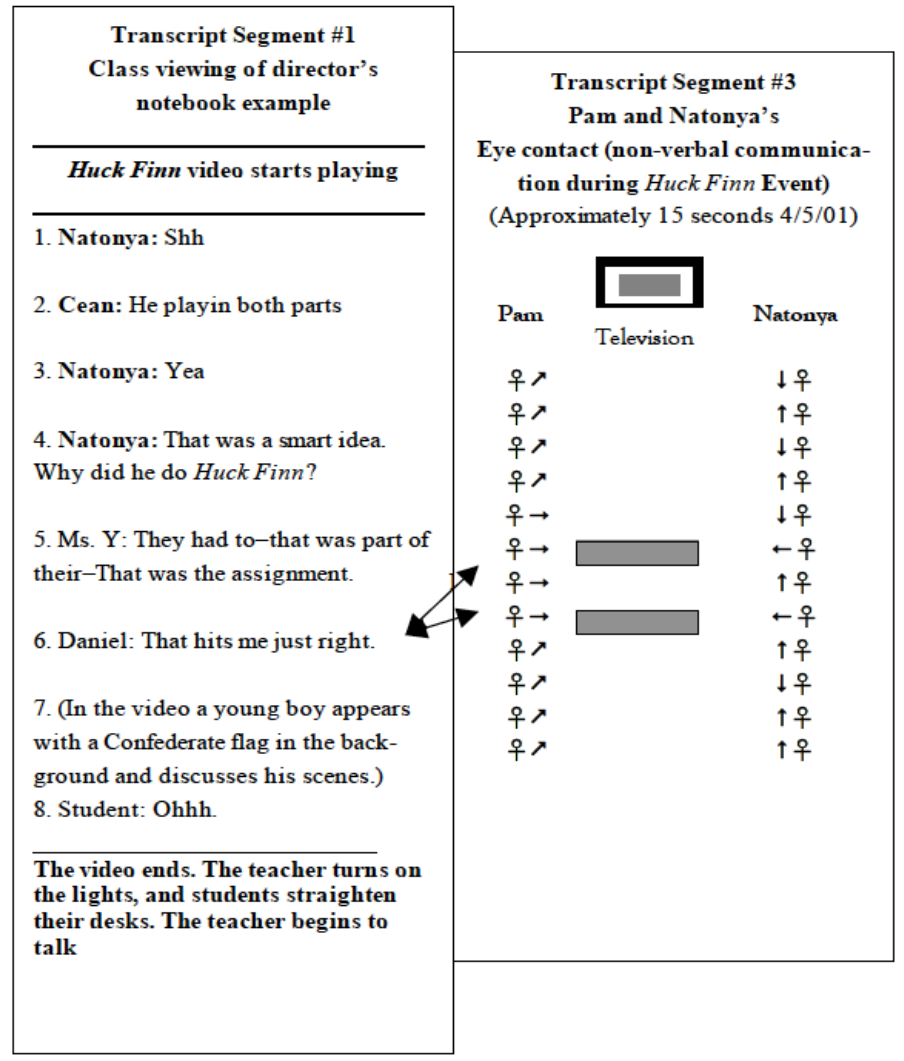

In line 6 of the classroom transcript, while the student's director notebook video example is playing, the student in the video transitions to his bedroom for a debriefing session and the confederate flag appears over his bed. The non-verbal 
transcript captures about 15 seconds when the Natonya and Pam engage in nonverbal communication.

1. This non-verbal interaction wasn't visible to me until the interview/conversation segment that follows in Table 2. It was then that I re-examined the young women's response to the aforementioned writer's notebook assignment and begin to understand what was occurring.

During an interview/conversation, as I sat across from Natonya in a room in the library, she describes the Huck Finn video:

\section{Table 3. Natonya on the Huck Finn Video}

Natonya: She (Pam) said Natonya look. I looked, I said okay yea, confederate flag. I you know, I found that shoot, actually I was offended. You know I mean cause usually when somebody, especially a White person with a confederate flag, you know that brings you back to segregation and um discrimination between Blacks and Whites, you know

After going back and looking at the video, it didn't appear that Natonya said "Yea ok." When I asked both Pam and Natonya about this observation during another interview conversation, they shared the following:

Table 4. Exploring Non-verbal communication with Natonya and Pam

\begin{tabular}{|l|}
\hline Natonya: It's like our -our problem is was really in our facial expression cause we look like(squints eyes). \\
\hline Pam: And Tonya said 'That's crazy!' \\
\hline Stephanie: So y'all do that sometimes \\
\hline Pam \& Natonya: Yea cause I just give her that look and sbe be like \\
(squints her eyes)
\end{tabular}

In another conversation with me, Natonya and Pam shared why they use the phrase the "inside thing" 
Table 5: Explicating the "Inside Thing"

Natonya: Naw because you know what that's-that's when the stuff-stuff comes in where the teacher get offended because you're offended and you tell her about it and then-then they'll write you up and it's like you really can't even do anything.

Pam and plus we need this credit too.

Natonya replies and my point exactly so, you be trying to and not to mess up to know.

Upon first glance, it seemed to me that Pam and Natonya were speaking about having no agency in the classroom because of the silencing processes that they frame. However, after (re)examining this dialogue in relation to the earlier one in Table 2, "inside thing", what I began to theorize is that it is due to the silencing that the girls carved out an oppositional space as a means to deal with issues that surface in the classroom. Analysis of other conversations led to another point of theoretical understanding of the role of non-verbal communication as actions and not silence in a traditional sense. During interview conversations identified in this iterative process of (re)visiting of the interview records, I identified instances in which Pam and Natonya discussed ways of supporting each other. Specifically, in one interview, Pam articulated this process as: Gotta stick together and Help each other out.

Findings from the study (POWER-CARTER, 2001) showed that two African American girls were constantly responding to, and negotiating, silencing processes in the curriculum and their interactions with others in the classroom and school context. My revisiting of these transcripts also led to my understanding that the two Pam and Natonya, the African American young women, created space(s) of silence, or rather spaces that looked like silence, through the non-verbal communication (e.g., eye rolls). These spaces allowed them to affirm and support each other as well as respond to oppressive aspects of their British literature curriculum and classroom, i.e., instances where what was proposed as "the" expected answer differed from their own understanding of the topic being discussed, the symbols inscribed, or the language used (e.g., definitions of beauty in Shakespeare).

Upon first glance, readers of these "bits" of conversation (HYMES, 1974) might interpret the discourse as reflecting a process in which the two African American young women, Pam and Natonya, were silenced. However, what became clearer through my ethnographic interview conversations and observations, as indicated in Table $2-5$ is that they were not passive or silenced. Instead, analysis showed that they often strategically used non-verbal communication as a way to safely respond to the silencing that was occurring in their classroom. Although scholars have rarely 
understood African American females' non-verbal communication in this way, (re) analysis of the literature led to the identification of work by Rickford (1999), in his study on African American language. Rickford noted that African American female participants used nonverbal communication and referred to it as, "cuteye" - a visual gesture that conveyed hostility or displeasure used to communicate and affirm each other. Rickford (1999) and Higginbotham's (1992) scholarship that I also located based on my findings in this study, begins to articulate the need for more closely examining silence and non-verbal communication, particularly as it relates to African American young women in classroom contexts.

Through the iterative process of searching for literature to support and/ or further explain the processes identified in my ethnographic study, I was able to locate support for my developing theoretical perspective as well as expanding the range of dimensions of this process to consider in future research. Related literature (CHRISTIAN, 1980; LADNER, 1972; CROSS, 1991; TATUM, 1997) also showed the importance of understanding the consequences for Black young women when silence(s) are simplified and/or not contextualized. The brief report of analyses presented in this section raises questions about the consequences for students when spaces of silence are not considered or are misunderstood by teacher as well as researchers. Therefore, the analyses presented in this section raises the question of how the failure to consider the ways in which silence and silencing are accomplished and understood by teachers and researchers alike, can have real consequences that are potentially life altering consequences for African American young women in school contexts. As Ladner (1972) articulated, these negative perspectives can be academically and psychologically damaging.

\section{THEORIZING SILENCE (S): CONSTRUCTING A SILENCE TRILOGY}

In this section, I present the silence trilogy, a conceptual perspective that has been nurtured and cultivated from a Black feminist ethos, a perspective that emphasizes theorizing the everyday experiences of Black women. This framework emerged from my work with, Pam and Natonya, who were introduced in the previous section and who became the focus of my analysis of silence in my ethnographic research process.

While the earlier framing was grounded in published literature, in this section, I make visible that the framing of the Silence Trilogy was also informed by my own experiences as a Black woman and daughter of an extraordinary Black woman. Collins (1991) writes that Black female scholars often are called "to produce facts 
and theories that will clarify a Black woman's standpoint for Black women (p. 37)." Thus, the silence trilogy can be thought of as an evolving framework informed by experiences of; Black women because it was developed by an African American woman scholar, to better understand and capture the nuanced complexity of how Black women navigate silence(s), as well as their resilience and genius. bell hooks, a Black feminist scholar (1991) further frames this process in the following excerpt from her article Theory as Liberatory Practice.

I find writing-theoretical talk-to be most meaningful that which invites readers to engage in critical reflection and to engage in the practice of feminism... This to me is what makes feminist transformation possible. Personal testimony, personal experience, is such fertile ground for the production of liberatory feminist theory because usually it forms the base of our theory making. While we work to resolve those issues (our need for literacy, for an end to violence against women and children, women's health and reproductive rights, our need for housing, for sexual freedom, etc. to name a few) that are most pressing in daily life, we engage in a critical process of theorizing that enables and empowers (p.8).

As noted above, bell hooks capture the spirit of theorizing that I drew on in the following section as I attempt to articulate a framework to capture silence(s) and the everyday experiences of Black women. Particularly, in the following part of this section, I will illustrate the relationship between silence, silenced, and silencing, what I frame as the Silence Trilogy and examine the implications each conceptualization has for and

\section{Silencing; Trilogy concept 1}

Silencing is situated in hegemonic activity and reproduces stereotypes and images of African American women that assault their identities. It is the case that whiteness has historical consequences on the African American female identity (COLLINS, 1990; McDONALD, 1999, GIDDINGS, 1984). Throughout U.S. history African American women have been characterized as "mammies" - the faithful obedient domestic servant, "matriarchs," overly aggressive unfeminine women, "welfare mothers," dependent on the government, and "whores," - sexually exotic women, among other personages.

When examined closely, these images support a white male interpretation of African American female identity. Williams (1999) writes, "Black [female] identity is subsumed in a social circumstance--an idea, a stereotype--that pins us to the underside of society and keeps us there out of sight/out of mind, out of knowledge of mind which is law "(as quoted in McDONALD \& FORD-AHMED, 1999, p. 31). Moreover, when using African American women's fiction to better understand 
silencing, Collins (1990) suggests that one consistent theme in the literature is that of physical and mental exploitation and silencing of African American female identity. Additionally, she argues the images that society has constructed attempt to create a socially assigned identity for African American females devoid of the multiple roles they play in society. These images seek to undermine the very nature of African American female voice by silencing the connections and common experiences African American women have encountered.

Silencing, from this perspective, is further identified as problematic for African American young women in the school context. Some African American female scholars have provided classroom data that illustrate how African American girls are characterized negatively in educational settings. Harrison (1997) and Fordham's (1993) work examines how African American girls are often positioned as loud and unsophisticated as they negotiate silencing in the school and classroom context with regard to how they dress, speak, and act. The consequences of not recognizing the experiences and contributions of African American females in greater society and the classroom context can be detrimental to African American female identity and lead to depression and a sense of failure and them becoming silenced (bell hooks, 1993). Being 'silenced' is another area that has important implications as it impacts the lived African American experience of African American females.

\section{Silenced: Trilogy Concept 2}

To frame the concept of silenced in the trilogy, I once again draw on the writing of bell hooks. bell hooks (1993) captures ways of being silenced in the following quotation:

\footnotetext{
Obviously the dearth of affirming images of Black femaleness in art, magazines, movies, and television reflect not only the racist white world's way of seeing us, but the way we see ourselves... the white dominated media presents this knowledge to us as if it is solely some defect of Black life that creates some aberrant and self-negating behavior, not white supremacy (p. 84).
}

As indicated in the quotation below, silenced can be view as submission to hegemonic processes and acceptance of negative images and stereotypes. This occurs when African American women internalize and give into stereotypes and take on the role of supporting and reproducing negative images of African American femaleness.

In an educational context, research (e.g., FINE, 1987) has shown that silenced or the process of being silenced can lead to real consequences for African American females (e.g., MORRIS, 2016). Pam and Natonya were often silenced. During an 
interview conversation, Pam talks about being put out of class unfairly, she shares and exchange she had with Mr. Bowman, an African American administrator, And I was telling Mr. Bowman-and bere be go Mr. Bowman, 'Well you know how it can be sometimes, and you just don't don't say nothing cause you really do need this credit to graduate. Silenced can facilitate being removed from a learning context and/or learning how to be totally submissive and devoid of self. It can also mean the lack of visual inclusion in the texts being read, and/or other forms of curriculum.

Pam and Natonya also experienced this in their British literature course. During an interview conversation, Pam and Natonya noted a class discussion on Shakespeare's sonnet, My Mistresses Eyes. During this particular class session, the teacher attempted to engage the class in a discussion on beauty. She states that universal beauty was that you bad to be tall, slender, long blonde bair, pretty blue eyes, rosy cheeks. Uh so if you weren't that you were not- not attractive -ugly. During an interview conversation, Pam and Natonya both shared as a result of this discussion that they felt the teacher was "trynah [folk phrase for trying to] say I am ugly. Such omission can lead to low self-esteem and depression, which can negatively impact academic achievement (POWER-CARTER, 2007; SIMS, 1983).

Also, silenced and/or being silenced can potentially lead to African American young women dropping out of school because of the tensions (e.g., constantly getting singled out for speaking too loudly and/ or acting in ways that do not reflect school culture) that they face in negotiating their own cultural background and identity to that of school (FORDHAM, 1993). This tension is further complicated because schools in the US and elsewhere primarily supports Eurocentric ways of knowing and engaging in (FINE, 1991/1995; WOODSON, 1933). Although silenced can have real consequences for African American females, it is problematic to think of silenced as fixed or static with regard to the experiences of African American females because doing so does not acknowledge their agency. Thus, silenced must be thought of as dynamic and changing because it might be the case that African American females feel silenced in one context and not in others, silenced in one classroom and not in another. For example, While Pam shares the experience that she had with the African American Administrator who told her to basically go to her British literature classroom class and be quiet because she needed the credit; she did not necessarily have this same experience in all of her classes.

\section{Silence: Trilogy concept 3}

Although silencing and silenced are constantly occurring, African American women are constantly responding to silencing in resilient ways creating spaces 
of agency and support to survive and respond to oppression (bell hooks, 1993; EVAN-WINTERS, 2005). I view those spaces of agency as silence. Silence is the intersecting voices of African American females that are embedded in particular realities and agency. Thus, silence does not necessarily mean that African American females have been muted and/or passive (CARTER, 2001; CHRISTIAN, 1980; MORRISON, 1994).

This extended definition of silence does not only view silence as an absence of voice or presence but also a productive space of agency that African American women have created to discuss and support each other (CARTER, 2001). When viewed as agency, silence can be thought of as strategies of engagement (e.g., choosing not speak, how to speak, and with whom to speak). Silence can also be a presence of agency that can be used to disrupt hegemonic language practices.

Moreover, expanding the current definition of silence can also be useful in understanding African American females' experiences in school context. Thinking of silence in this way challenges educators to question and examine more closely how their classroom practices and research positions African American females negatively and to seek out the alternative ways African American young women may engage in learning as a means to be successful. While it is clear that some African American women have participated and may participate in different parts of the silence trilogy at different times and contexts, it is also important to note that African American women are constantly responding to silencing and negotiate their identities in dynamic and powerful ways (POWER-CARTER, 2001).

Many African American women, like the young women in my studies and in my community, have been speaking for quite some time. However, how this is voiced or heard is still subject of limited research. Once again, I draw on bell hooks (1989) to capture issues that this raises for further research:

[Black women's] speech was often the soliloquy the talking into thin air, the talking to ears that do not hear you... The voices of Black women giving orders, making threats, fussing could be tuned out, could become a kind of background music, audible but not acknowledged as significant speech (p. 6).

In this quote, bell hooks (1989) describes African American females as speaking, but she also notes that their voices are often unacknowledged and insignificant.

The silence trilogy presented in this section was proposed as a conceptual way to deconstruct the dominant perception of the silence(s) that surround African American women's experiences in order to make visible complexities. This trilogy does not negate the potential multiple possibilities of meanings and 
definitions that silence, silencing and silenced might hold for particular women in particular contexts. The silence trilogy also frames a basis for understanding that the traditional definition of silence as non-participatory can be problematic, given that it renders the sophisticated epistemologies framed in this trilogy that Black women have created to communicate with each other as invisible and does not fully capture how agency functions with regards to African American female identity.

The telling case that emerged in my work with Pam and Natonya was critical in helping me unpack the silence trilogy. As I have argued throughout this paper, my own experiences as a Black woman were also critical to my understandings. The following section further illuminates how my work with Pam and Natonya was reflexive and part of complicating and re-framing silence.

\section{DISCUSSION: FURTHER THOUGHTS AND POTENTIAL DIRECTIONS}

In framing issues of silence, I demonstrated how the reflexive processes could inform research in complex phenomena of everyday lived experiences of particular groups within society and educational contexts. Through the research that I presented, I made visible why it is important that we (researchers and scholars) provide spaces and opportunities for scholars of color to share their processes of research and constructing theoretical understandings grounded in the ways of knowing and understanding the communities with whom we work. My exploration through research, literature reviews, and personal reflexivity asks us to ponder the following questions: What research approaches, literacy theories, and theorizing practices do we need to draw on as we educate linguists and language and literacy scholars in understanding the nuanced ways scholars of color navigate their work? How might the experiences and understanding of these researchers inform larger set of issues around equity and inclusion?

Further, the silence trilogy developed in this paper provides a means to explicate and expand current definition of silence(s) that neglect to account for the spaces of possibility and agency that Black young women (and by extension other groups), particularly in schools, have created for themselves. As I have demonstrated in this paper, explicating silence(s) is useful in helping educators understand the educational experiences of African American young women. By not explicating silences, educators and educational researchers run the risk of reproducing a cycle that can be viewed and experienced by some as social and academic violence that can negatively positions African American young women (and other groups) in educational contexts. The lack of understanding of the importance of examining silence, silencing and silenced, also create the potential 
to facilitate or create blind spots and thus lead to a process of overlooking and/ or misunderstanding the culturally supportive spaces that African American young women create for themselves, which might have the potential of influencing the academic achievement of this group of students.

In this paper, I have identified issues that I argue the field of education research must consider ways to educate ourselves about how silences function within classrooms. I also presented examples from my ethnographic research and the work of others that makes visible the importance of closely examining the spaces of silence that African American females create and maintain for each other to affirm their cultural identity. In unfolding the interview conversations, I also made visible why establishing relationships is crucial to gain insider understandings and reasoning about the social. The interview processes made visible why it is important that as researchers, we not examine young Black women in ways that are intrusive, but rather conduct our research in ways that are sensitive to Black young women's cultural identities and epistemologies. I am not suggesting that we examine these spaces of silence as ways to homogenize the experiences of African American females but rather as a way to contextualize and better understand their experiences and recognize how silence(s) inform African American female experiences in greater society as well as the classroom context.

Furthermore, through a review of literature and presenting analysis from my ethnographic research, I framed ways of expanding the traditional view of silence and made visible how this approach affords the field an opportunity to reconceptualize and critique how they understand silences with regard to African American females' experiences and other historically marginalized groups. It also has the potential to make visible spaces of agency and possibility that work to reenvision African American female experiences and identity in more positive ways and also acknowledge those scholars of color who are uniquely positioned to see and capture their experiences more fully.

\section{$\overline{\text { REFERENCES }}$}

ADICHIE, C. N. (2009). The danger of a single story. TED Talk. Retrieved from https://www. ted.com/talks/chimamanda_adichie_the_danger_of_a_single_story? language $=$ en

ANYON, Y. et al (2014). The persistent effect of race and the promise of alternatives to suspension in school discipline outcomes. Children and Youth Services Review, 44, 379-386. 
AKBAR, N. (1985). Our destiny: Authors of a scientific revolution. In H. P. McAdoo \& J. L. McAdoo (Eds.), Sage focus editions, Vol. 72. Black children: Social, educational, and parental environments (p. 17-31). Sage Publications, Inc.

AGAR, M. (1994). Language shock: Understanding the culture of conversation. New York: William Marrow.

BAUGH, J. (2010). Black street speech: Its bistory, structure, and survival. University of Texas Press.

BEACH, R.; BLOOME, D. (2019). Languaging relations for transforming the literacy and language arts classroom. New York: Routledge.

BETHUNE, M. (2001) Mary McLeod Bethune: Building a better world: essays and selected documents. Indiana: Indiana University Press.

BETHUNE, M. M. (1938). Clarifying our vision with the facts. The Journal of Negro History, $23(1), 10-15$.

BLOOME, D.; CHRISTIAN, B.; OTTO, S.; CARTER POWER, S.; SHUART, N. (2005). Discourse analysis and the study of classroom language and literacy events: A microethnographic perspective. Mahwah, New Jersey: Lawrence Erlbaum.

bell hooks. (1989). Talking back: thinking feminist, tbinking black. Boston: South End Press.

bell hooks. (1991). Theory as liberatory practice. Yale JL \& Feminism, 4, 1.

bell hooks. (1993). Sisters of the yam. Boston, MA: South End Press.

BLAKE, J. J.; BUTLER, B. R.; LEWIS, C. W.; DARENSBOURG, A. (2011). Unmasking the inequitable discipline experiences of urban Black girls: Implications for urban educational stakeholders. The Urban Review, 43(1), 90-106.

BROWN, A. F.; BLOOME, D.; MORRIS, J. E.; POWER-CARTER, S.; WILliS, A. I. (2017). Classroom conversations in the study of race and the disruption of social and educational inequalities: A review of research. Review of Research in Education, 41 (1), $453-476$.

CAMERA, L. (2017). Black Girls Are Twice as Likely to Be Suspended, In Every State. U.S. News and World Report. Retrieved from: https://www.usnews.com/news/educationnews/articles/2017-05-09/black-girls-are-twice-as-likely-to-be-suspended-in-everystate 
CARANFA, A. (2004). Silence as the foundation of learning. Educational Theory, 54, (2), 211-230.

CARTER, S. (2001). The possibilities of silence: African-American female cultural identity and secondary English classrooms. Unpublished doctoral dissertation, Vanderbilt University,Nashville, Tennessee.

CHAVOUS,T.; COGBURN, C. D. (2007). Superinvisible women: Black girls and women in education. Black Women, Gender \& Families, 1(2), 24-51.

CHEUNG, K. (1993). Articulate Silences. Ithica, New York: Cornell University Press

CHRISTIAN, B. (1980). Black women novelists: The development of a tradition, 1892-1976. Westport, CT: Greenwood Press.

COLLINS, P. H. (1990). Black feminist thought: Knowledge, consciousness, and the politics of empowerment. Cambridge, MA: Unwin Hyman.

COOPER, A. J. (1892/1988). A Voice from the South. Xenia, Ohio: Aldine Printing House.

CROSS, W. E. (1991). Shades of Black: Diversity in African-American identity. Philadelphia. P.A.: Temple University Press.

DILLARD, C. B. (2011). Learning to remember the things we've learned to forget. Qualitative inquiry and global crises, 226-243.

DU BOIS, W. E. B. (1903). The souls of black folk. NewYork: Bantam.

EVANS-WINTERS, V. E. (2005). Teaching black girls: Resiliency in urban classrooms (Vol. 279). Peter Lang.

FERNANDES, L. (2003). Transforming feminist practice:Non-violence, social justice and the possibilities of a spiritualized feminism. San Francisco: Aunt Lute Books

FERNANDEZ, B. (2018). Silence as a Form of Agency? Exploring the Limits of an Idea. In Etbical Responsiveness and the Politics of Difference (pp. 187-204). Palgrave Macmillan, Cham.

FINE, M. (1991). Framing dropouts: Notes on the politics of an urban bigh school. Albany: SUNY Press.

FINE, M. (1995). Silencing and literacy. In V. Gadsden \& D. Wagner (Eds.), Literacy among African-American youth (pp. 201-222). Cresskill, New Jersey: Hampton Press. 
FORDHAM, S. (1993). Those loud black girls: (Black) women, silence, and gender "Passing" in the academy. Antbropology Quarterly, 24, (1), 3-32.

FULLER, M. (1980). Black girls in a London comprehensive school. Schooling for women's work, 52-65.

GIDDINGS, P. (1984). When and where I enter: The impact of women on race and sex in America. New York: William Morrow.

GILLAM, R. (2017). Representing black girlhood in Brazil: Culture and strategies of empowerment. Communication, Culture \& Critique, 10(4), 609-625.

GUY-SHEFTALL, B. (Ed.). (1995). Words of fire. New York: New Press.

GUMPERZ, J.; D. HYMES (Eds). (1972). Directions in sociolinguistics: The ethnography of communication. NewYork: Holt, Rinehart and Winston.

GUMPREZ, J. (1986). Discourse strategies. New York: Cambridge University Press.

GUMPERZ, J. J. (1984). Communicative competence revisited. Cognitive Science Program, Institute of Cognitive Studies, University of California at Berkeley.

HALL, S.(1990). Cultural identity and diaspora. In J. Rutherford (Ed.), Identity, community, culture, difference (pp. 222-237). London: Lawrence \& Wishart.

HARRISON, J. (1997). Lisa's quiet fight: School structure and adolescent females. In K. Lomotey (Ed.), Sailing against the wind: African American and women in U.S. education (pp. 45-53). New York: SUNY Press.

HENRY, A. (1994). The empty shelf and other curricular challenges of teaching for children of African descent. Urban Education, 29(3), 298-319.

HIGGINBOTHAM, E. (1992). African-American women's history and metalanguage of race. Signs: Journal of Women in Culture \& Society 17 (2), 251-274.

HILL, P. (Ed.). (1998). Call and response. New York: Houghton Mifflin.

HURSTON, Z. N. (1928)." How It Feels to Be Colored Me. New York: World Tomorrow Press.

HUEY-LI LI. 2002. Silence and Silencing Silences. Pbilosopby of Education Society 2001 Yearbook. Urbana, IL: University of Illinois Press. 
HYMES, D. (1974). Foundations of sociolinguistics. Philadelphia: University of Pennsylvania Press.

JONES, N. (2009). Between good and ghetto: African American girls and inner-city violence. New Brunswick, NJ: Rutgers University Press.

LADNER, J. (1972). Tomorrow's Tomorrow: The Black woman. Double Day \& Company: Garden City, New York. Lanehart, S. (2002). Sista Speak: Black women kinfolk talk about language and literacy. Austin, TX: University of Texas Press.

LADSON-BILLINGS, G. (1994). The dream keepers. San Francisco: Jossey-Bass.

LEE, C. (2001). Unpacking culture, teaching, and learning: A response to the pedagogy of power. In (Eds.), Watkins, W., Lewis, J., Chou, V. (2001). Race and Education, The Roles of History and Society in Educating African-American students (pp.89-99). Allyn Bacon: Boston, MA.

LEWIS, A. E. (2003). Race in the schoolyard: Negotiating the color line in classrooms and communities. Rutgers University Press.

LORDE, A. (1982). Zami: A new spelling of my name. Trumansberg, NY: Crossing Press.

MCDONALD, T.; ORD-AHMED, T. (Eds.). (1999). Nature of a sistuh. Durham, NC: Carolina Academic Press.

MADDUX, D. (1997). The miseducation of African Americans in public high school. In K. Lomotey (Ed.), Sailing against the wind: African American and women in U.S. education (pp. 63-69). New York: SUNY Press.

MAHER, F.; TETREAULT, M. (1997). Learning in the dark: How assumptions of whiteness

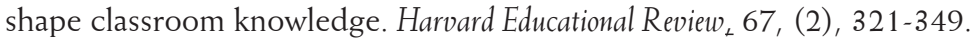

MARRIOTT, DONNA M. (2003). Ending the silence. Pbi Delta Kappan, 84(7), 496-501.

MUHAMMAD, G. E.; MCARTHUR, S. A. (2015). "Styled by their perceptions": Black adolescent girls interpret representations of Black females in popular culture. Multicultural Perspectives, 17(3), 133-140.

MUHAMMAD, G. E. (2012). Creating spaces for Black adolescent girls to "write it out!". Journal of Adolescent \& Adult Literacy, 56(3), 203-211. 
MITCHELL, J. C. (1984). Typicality and the case study. In R. Ellen (Ed.), Ethnographic research: A guide to general conduct (pp. 238-241). New York:Academic Press.

MIRZA, H. S. (Ed.). (1997). Black British feminism: A reader. Taylor \& Francis.

MORRIS, E. W. (2007). "Ladies" or "loudies"? Perceptions and experiences of black girls in classrooms. Youth \& Society, 38(4), 490-515.

MORRIS, M. (2016). Pushout: The criminalization of Black girls in schools. New York: New Press.

MORRISON, T. (1993). Nobel Prize lecture. [on-line] Available: http://nobel.sdsc.edu/ literature/laureates/1993morrison-lecture.html

MORRISSON, T. (1994). The bluest eye. New York: First Plumb.

MORGAN, M. (1996). Conversational signifying: Grammar and indirectness among African American women. Studies in interactional sociolinguistics, 13, 405-434.

MORGA, C.; ANZALDUA, G. (1981). The bridge called my back:writings by radical women of color. Watertown: MA: Persephone Press.

MUHAMMAD, G. E.; HADDIX, M. (2016). Centering Black girls' literacies: A review of literature on the multiple ways of knowing of Black girls. English Education, 48(4), 299-336.

PARIS, D.; WINN, M. T. (Eds.). (2013). Humanizing research: Decolonizing qualitative inquiry with youth and communities. Sage Publications.

POWER-CARTER; S. ZAKERI, B.; KUMASI, K. (2019). Sawubona: Agency, Change, and Power. In Languaging Relationships Across Social Worlds: Re-theorizing the Teaching and Learning of Literacy in the Language Arts. New York. Routledge.

POWER-CARTER, S. (2007). "Reading all that White crazy stuff": Black young women unpacking whiteness in a high school British literature classroom. Journal of Classroom Interactions.

PAUL, D. G. (2003). Talkin'back: Raising and educating resilient Black girls. Connecticut: Greenwood Publishing Group.

RICKFORD, J. R. (1999). African American vernacular English. Malden, MA: Blackwell. 
ROLLOCK, N. (2007). Why Black girls don't matter: Exploring how race and gender shape academic success in an inner city school. Support for Learning, 22 (4), 197-202.

SAN PEDRO, T. J. (2015). Silence as shields: Agency and resistances among Native American students in the urban Southwest. Research in the Teaching of English, 132-153.

SEALEY-RUIZ, Y. (2016). Why Black girls' literacies matter: New literacies for a new era. English Education, 290-298.

SKIBA, R. J.; MICHAEL, R. S.; NARDO, A. C.; PETERSON, R. L. (2002). The color of discipline: Sources of racial and gender disproportionality in school punishment. The Urban Review, 34, 317-342.

SMITH, B. (1985). Some home truths on the contemporary black feminist movement. The Black Scholar, 16(2), 4-13.

SMITHERMAN, G.; MITHERMAN-DONALDSON, G. (1986). Talkin and testifyin: The language of Black America (Vol. 51). Detroit:Wayne State University Press.

STREET, B. V. (2014). Social literacies: Critical approaches to literacy in development, etbnograpby and education. Routledge.

TANNEN, D.; SAVILLE-TROIKE, M. (1985). Perspectives on silence. Norwood, New Jersey: Ablex Publishing Corporation.

TATUM, B. D. (1997). Why are all the Black kids sitting together in the cafeteria? New York: Basic Books.

TUCK, E. (2009). Suspending damage: A letter to communities. Harvard Educational Review, $79(3), 409-428$.

WILLIS, A. I. (2008). On critically conscious research: Approaches to language and literacy. New York: Teachers College Press.

WINN, M. T. (2019). Girl time: Literacy, justice, and the school-to-prison pipeline. Teachers College Press.

WOODSON, C. (1933). The miseducation of the Negro. Washington, D.C: The Associated Publishers.

WUN, C. (2016). Unaccounted foundations: Black girls, anti-Black racism, and punishment in schools. Critical Sociology, 42(4-5), 737-750. 
ZAHARLICK, A.; GREEN, J. L. (1991). Ethnographic research. In J. Flood, J Jensen, D. Lapp, \& J. Squire (Eds.), Handbook of research on teaching the language arts (pp. 205-225). New York: Macmillan.

ZEMBYLAS, M.; MICHAELIDES, P. (2004) The sound of silence in pedagogy. Educational Theory, 54 (2), 193-210.

Recebido: $23 / 03 / 2020$

Aceito: 26/03/2020

Publicado: 31/03/2020 